Gut, 1981, 22, 663-668

\title{
Nicotinic acid test in the diagnosis of Gilbert's syndrome: correlation with bilirubin clearance
}

\author{
W RÖLLINGHOFF, ${ }^{*}$ G PAUMGARTNER, AND R PREISIG \\ From the Department of Clinical Pharmacology, University of Berne, Switzerland, and Department of Medicine \\ II, Klinikum Grosshadern, University of Munich, Germany
}

SUMMARY A provocation test with nicotinic acid (50 mg intravenously) was performed in 13 patients with Gilbert's syndrome and seven healthy volunteers to investigate the diagnostic value of several test parameters and to correlate them with the bilirubin clearance. The maximal increment of unconjugated serum bilirubin, the retention at four hours, and the area under the bilirubin concentration time curve. (AUC) were measured. Significant differences between patients and controls were found with regard to the $\operatorname{AUC}(7 \cdot 95 \pm \mathrm{SD}, 3 \cdot 29 \mathrm{mmol} / \mathrm{min} / 1 \mathrm{vs} .3 \cdot 08 \pm 0 \cdot 57 ; \mathrm{P}<0 \cdot 001)$, the increment of unconjugated bilirubin $(24 \cdot 1 \pm 7 \cdot 1 \mu \mathrm{mol} / \mathrm{l}$ vs. $10 \cdot 2 \pm 3 \cdot 2 ; \mathrm{P}<0 \cdot 001)$ and the retention $(77 \cdot 7 \pm 8 \cdot 9 \%$ vs. $45 \cdot 8 \pm 27 \cdot 4 \% ; \mathrm{P}<0 \cdot 02)$. Of those, the AUC discriminated best between patients and controls. Five patients with Gilbert's syndrome had normal serum bilirubin concentrations $(<17 \cdot 1 \mu \mathrm{mol} / \mathrm{l}=1 \mathrm{mg} \%)$ at the time of the study, but abnormal AUC and bilirubin increment. A significant correlation was found between the bilirubin clearance and the retention $(r=-0.96$; $\mathbf{P}<0.001)$ as well as the AUC $(r=-0.82 ; \mathrm{P}<0.05)$ but not with the bilirubin increment. This simple test may be used to assess the disturbance of bilirubin clearance in Gilbert's syndrome.

Gilbert's syndrome is characterised by the existence of chronic low-grade unconjugated hyperbilirubinaemia in otherwise healthy persons. The hyperbilirubinaemia in this condition is presumed to result from an abnormality in the hepatic clearance of unconjugated bilirubin. Such an abnormality has, in fact, been demonstrated by the injection of isotopically labelled bilirubin. ${ }^{1}$ Berk et $a .^{2}$ could show by multicompartmental analysis that the reduced hepatic bilirubin clearance in Gilbert's syndrome is the result of a defect in both hepatic bilirubin uptake and conjugation. This interpretation is compatible with the finding of reduced hepatic bilirubin UDP-glucuronyltransferase activity in patients with Gilbert's syndrome. ${ }^{3}$ The diagnosis is usually restricted to patients in whom results of liver function tests are normal and in whom there is no evidence of overt haemolysis.

Fluctuations in serum bilirubin levels can make the diagnosis difficult because bilirubin plasma concen-

\footnotetext{
*Address for correspondence: Dr W Röllinghoff, Department of Medicine II, Klinikum Grosshadern, Marchioninistr. 15 D - 8000 München 70, Germany.

Received for publication 17 February 1981
}

trations are frequently below the level which causes clinical jaundice, and many cases presumably are unrecognised. Therefore, Fromke and Miller $^{4}$ suggested a provocation test with nicotinic acid in patients with suspected Gilbert's syndrome. Mattei ${ }^{5}$ was the first to observe that nicotinic acid given intravenously causes a rise of unconjugated serum bilirubin. This phenomenon has also been studied in patients with haemolytic and hepatic diseases as well as in normal subjects. ${ }^{6-9}$ It has been suggested that the nicotinic acid test is of diagnostic value in patients with Gilbert's syndrome. ${ }^{410-12}$

Recently, Ohkubo et al. ${ }^{12}$ could show that the increase of unconjugated serum bilirubin induced by nicotinic acid is the result of complex mechanisms which include increased erythrocyte fragility, increased splenic heme-oxygenase activity, and increased formation of bilirubin in the spleen. Reduced hepatic clearance of bilirubin may be a major determinant of the degree of unconjugated hyperbilirubinaemia observed after injection of nicotinic acid in patients with Gilbert's syndrome. As the relationship between the nicotinic acid induced rise in serum bilirubin and the disturbance of hepatic 
bilirubin clearance in patients with Gilbert's syndrome has not been studied, we decided to undertake the present investigation.

\section{Methods}

SUBJECTS AND DIAGNOSTIC PROCEDURES

Thirteen patients ( 10 males, three females, age 20-58 years) with Gilbert's syndrome were studied. All subjects were ambulatory. The diagnosis was based on the following criteria: history of recurrent, light jaundice; presence of unconjugated hyperbilirubinaemia, normal physical findings (except for episodes of scleral icterus); normal results of routine liver function tests and haematological investigations. Seven healthy volunteers (five males, two females, age 26-45 years) served as controls. Physical examination as well as the routine laboratory tests showed no signs of liver disease or enhanced haemolysis.

In all patients a quantitative assessment of hepatic function was performed. After a small breakfast consisting of tea and toast, the galactose elimination capacity (GEC) was measured by Tygstrup's method. ${ }^{13}$ Thereafter, a single injection of bromsulphalein (BSP) $(5 \mathrm{mg} / \mathrm{kg}$ body weight) was administered to determine the initial plasma disappearance rate constant $\left(\mathrm{k}_{1}\right)$ and the BSP retention $(\% / 45 \mathrm{~min}){ }^{14}$ The aminopyrine breath test was carried out according to Bircher et al. ${ }^{15}$ in order to assess hepatic microsomal function.

Haematological disorders with haemolysis were excluded by the following determinations: red blood cell count, haemoglobin concentration, reticulocyte count, blood smear, Coombs test, haemoglobin electrophoresis, red blood cell enzymes and red blood cell osmotic fragility. Red blood cell survival was estimated by the ${ }^{51} \mathrm{Cr}$-technique. ${ }^{16}$

\section{ESTIMATED BILIRUBIN CLEARANCE}

Hepatic bilirubin clearance was calculated as described by Kutz et al. ${ }^{17}$ In comparison with the direct measurement of bilirubin clearance with ${ }^{14} \mathrm{C}$-bilirubin (Berk et al. ${ }^{2}$ ) this indirect method is simple and convenient. Besides erythrocyte half-life (RBC t1/2), blood volume (BV), unconjugated serum bilirubin (SB), and haemoglobin concentration (HB) were measured. Under steady-state conditions bilirubin excretion equals bilirubin production (BP) and bilirubin clearance $\left(\mathrm{Cl}_{\mathrm{B}}\right)$ can be calculated according to the following equation:

$$
\mathrm{Cl}_{\mathrm{B}}=\frac{\mathrm{BP}}{\mathrm{SB}}=\frac{\mathrm{BV} \times \mathrm{HB} \times 6 \cdot 21 \times 100}{\mathrm{SB} \times \mathrm{RBC} \mathrm{tl} / 2}
$$

(6.21 mmol bilirubin derives from $1 \mathrm{~g} \mathrm{HB})$
The results of this indirect method are in good agreement with direct measurements of bilirubin clearance. In 22 patients with Gilbert's syndrome Kutz et al. ${ }^{17}$ calculated a reduced hepatic bilirubin clearance $(15 \pm \mathrm{SD} 4 \mathrm{ml} / \mathrm{min}$; normal $48 \pm 19)$ as compared with $16 \pm 5 \mathrm{ml} / \mathrm{min}$ in 11 patients (normal $47 \pm 10$ ) studied by Berk et al. ${ }^{2}$

\section{NICOTINIC ACID TEST}

In accordance with Mattei ${ }^{5} 50 \mathrm{mg}$ nicotinic acid (Niconacid, Wander, Switzerland (nicotinic acidsodium, $100 \mathrm{mg} / \mathrm{ml}$ ) were injected intravenously within 30 seconds and blood samples for determination of total and unconjugated bilirubin were taken at $0,30,60,90,120,180$, and 240 minutes. All blood samples were cooled and stored in the dark until the end of the test. Measurements of serum bilirubin were made on the same day.

In patients and controls the test was carried out in the morning after an overnight fast. All subjects described an internal feeling of warmth and burning sensation; these symptoms and the flush disappeared within five to 10 minutes after injection. Some subjects mentioned a transitory metallic taste. No other undesirable effects of nicotinic acid were observed.

The following parameters were derived from the unconjugated bilirubin concentration time curve:

1. The maximal increment of unconjugated bilirubin (peak value minus pre-injection value).

2. The rise of serum unconjugated bilirubin at $\mathbf{2 4 0}$ minutes after nicotinic acid injection expressed as percentage of maximal serum bilirubin increase. This value, for brevity, will be called bilirubin retention (R); it was calculated according to the following equation:

$$
\mathrm{R}=\frac{\mathrm{C}_{240}-\mathrm{C}_{0}}{\mathrm{C}_{\text {peak }}-\mathrm{C}_{0}} \times 100(\%)
$$

3. The area under the unconjugated bilirubin concentration time curve (AUC) 0 to four hours after nicotinic acid injection, calculated according to the trapezoidal method.

\section{ANALYTICAL PROCEDURES}

Total and conjugated serum bilirubin concentrations were determined by the method of Michaelsson $e t$ al. ${ }^{18}$; normal values for total bilirubin are less than $17 \cdot 1 \mu \mathrm{mol} / \mathrm{l}(1 \mathrm{mg} \%) .{ }^{19}$ Galactose concentrations in plasma and urine were measured by a galactose oxidase method..$^{20}$ Plasma BSP concentrations were determined with a Unicam spectrophotometer (Unicam Instruments, Cambridge, England) at $\mathbf{5 8 0}$ nm, after dilution with phosphate buffer and alkalinisation with $20 \% \mathrm{KOH}$, using appropriate blanks. ${ }^{21}$ 
Table 1 Serum bilirubin, liver function tests, and estimated bilirubin clearance in patients with Gilbert's syndrome

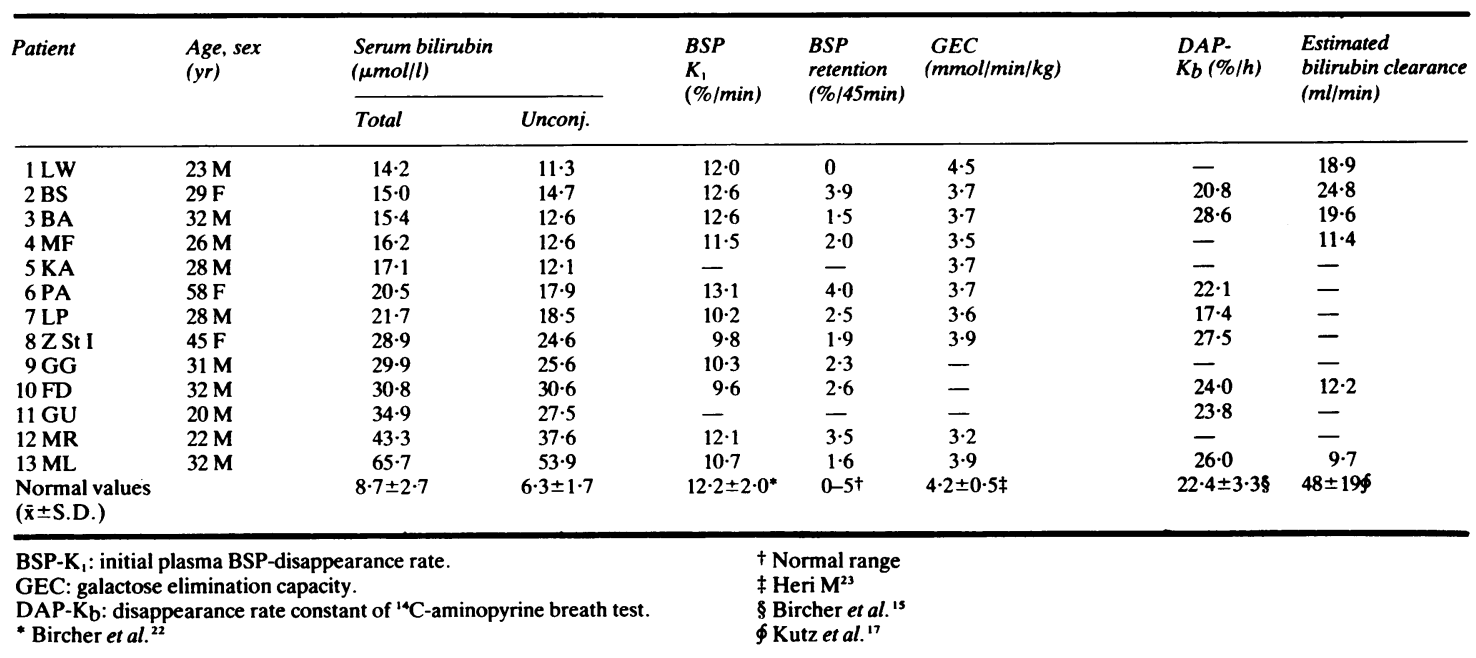

STATISTICAL ANALYSIS

Student's $t$ test was used for group comparison. Differences with $\mathrm{P}<0 \cdot 05$ were considered to be statistically significant. Unless stated otherwise, the results are given as means \pm standard deviation.

\section{Results}

SERUM BILIRUBIN, LIVER FUNCTION, AND

ERYTHROCYTE HALF-LIFE

Total fasting serum bilirubin concentrations ranged from $14 \cdot 2-65 \cdot 7 \mu \mathrm{mol} / \mathrm{l}(27 \cdot 2 \pm 14 \cdot 7)$ in patients and from $4.6-13.5 \mu \mathrm{mol} / 1(8 \cdot 7 \pm 2 \cdot 7)$ in controls (Table 1). The initial plasma BSP-disappearance rate $\left(K_{1}\right)$ ranged from $9 \cdot 6-13 \cdot 1 \% / \mathrm{min}$, thus being normal in all patients studied. Similarly, results of BSP retention (range $0-4 \% / 45 \mathrm{~min}$ ), the disappearance rate constant $\left(\mathrm{K}_{\mathrm{b}}\right)$ of aminopyrine breath test (range $17 \cdot 4-28.6 \% / \mathrm{h}$ ) and GEC (range $3.2-4.5 \mathrm{mmol} /$ $\mathrm{min} / \mathrm{kg}$ ) were within normal limits (Table 1). There were no signs of overt haemolysis. The half-life of ${ }^{51} \mathrm{Cr}$-labelled red cells was normal, except in two where it was slightly reduced (range 21 to 29 days).

EFFECTS OF NICOTINIC ACID ON SERUM BILIRUBIN The nicotinic acid injection caused a rise of unconjugated bilirubin in patients as well as in controls (Fig. $1)$. In the 13 patients with Gilbert's syndrome the unconjugated bilirubin increased from an initial value of $23 \cdot 1 \pm 12 \cdot 3 \mu \mathrm{mol} / 1$ to a peak value of $47 \cdot 2 \pm 14 \cdot 5$ $\mu \mathrm{mol} / \mathrm{l}$ at 120 minutes. In contrast, controls showed a peak of $16.5 \pm 2.9 \mu \mathrm{mol} / \mathrm{l}$ at 90 minutes (pre-injection value $6 \cdot 3 \pm 1 \cdot 7 \mu \mathrm{mol} / \mathrm{l})$. The increment of $24 \cdot 1 \pm 7 \cdot 1$ $\mu \mathrm{mol} / \mathrm{l}$ was significantly greater than that of $10 \cdot 2 \pm 3 \cdot 2$ $\mu \mathrm{mol} / \mathrm{l}$ obtained in seven healthy subjects $(\mathrm{P}<0 \cdot 001$, Fig. 2).

In patients with Gilbert's syndrome a significant amount of unconjugated bilirubin $(39 \cdot 7 \pm 15 \cdot 6$ $\mu \mathrm{mol} / \mathrm{l})$ remained in the serum four hours after nicotinic acid injection $(77 \cdot 7 \pm 8.9 \%$ retention) as compared with controls $(11 \cdot 1 \pm 3.3 \mu \mathrm{mol} / \mathrm{l}$; $45 \cdot 8 \pm 27 \cdot 4 \%$ retention; $P<0 \cdot 02$ ). As shown in Fig. 2 the AUC was significantly greater in patients with Gilbert's syndrome $(7 \cdot 95 \pm 3 \cdot 29 \mathrm{mmol} / \mathrm{min} / \mathrm{l})$ than in controls (3.08 $\pm 0.57 \mathrm{mmol} / \mathrm{min} / 1 ; \mathrm{P}<0.001)$.

In five patients with Gilbert's syndrome initial total serum bilirubin concentrations at the time of investigation were normal-that is, less than $17 \cdot 1 \mu \mathrm{mol} / \mathrm{l}$. After nicotinic acid injection, however, a positive test result was found in all patients (Table 2). The AUC in Gilbert's patients with normal and with raised bilirubin levels was significantly greater $(6.37 \pm 1.09$ $\mathrm{mmol} / \mathrm{min} / \mathrm{l} ; \quad \mathrm{P}<0.001$, and $8.94 \pm 3.87 ; \quad \mathrm{P}<0.01$ respectively) than in controls (3.08 $\pm 0 \cdot 57)$.

When comparing the increments of unconjugated serum bilirubin between patients with Gilbert's syndrome and controls $(10 \cdot 2 \pm 3 \cdot 2 \mu \mathrm{mol} / \mathrm{l})$ significant differences were found not only for patients with raised bilirubin levels $(23.4 \pm 6.8 \mu \mathrm{mol} / \mathrm{l} ; \mathrm{P}<0.001)$, but also for those with normal bilirubin levels $(25 \cdot 1 \pm 8 \cdot 1 ; \mathrm{P}<0 \cdot 02$; Table 2).

\section{CORRELATION OF NICOTINIC ACID TEST}

PARAMETERS WITH BILIRUBIN CLEARANCE

In six patients with Gilbert's syndrome the nicotinic acid test parameters were correlated with the bilirubin clearance. As shown in Fig. 3 a significant correlation between the bilirubin clearance and the 
Fig. 1 Serum total and unconjugated bilirubin after giving nicotinic acid to 13 patients with Gilbert's syndrome $(O)$ and seven controls $(\triangle)$. Figures are means \pm standard deviations.
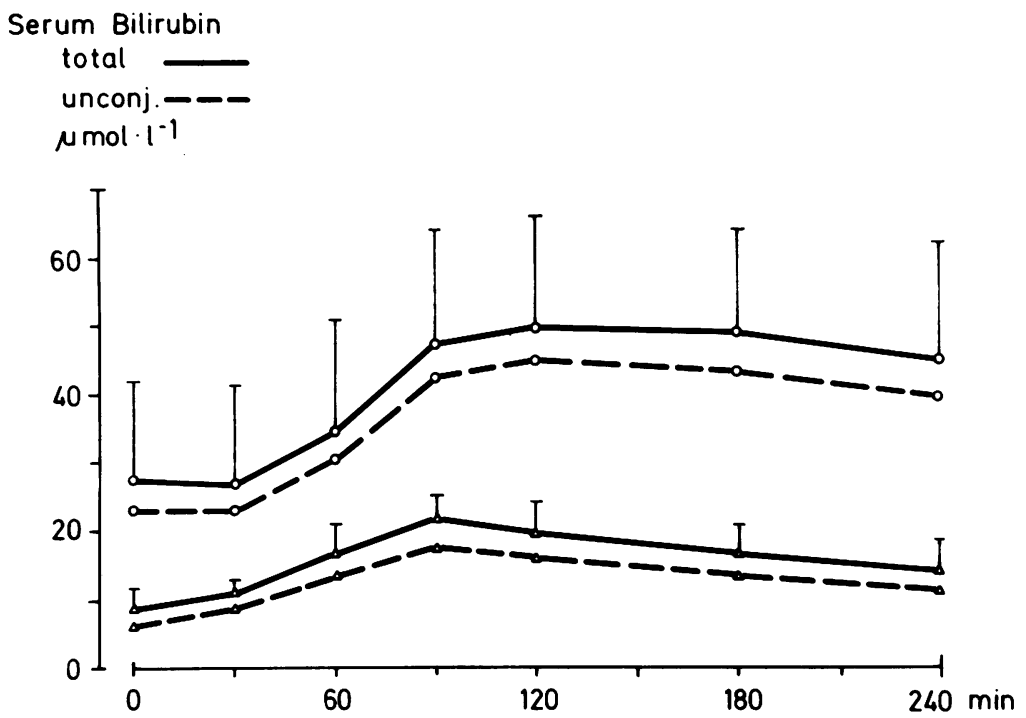

retention $(r=-0.96 ; \mathrm{P}<0.001)$ as well as the AUC $(r=-0.82 ; \mathrm{P}<0.05)$ was found. The correlation of the bilirubin clearance with the maximal increment $(r=-0 \cdot 44)$ was not significant.

\section{Discussion}

The aim of the present study was to assess the diagnostic value of the nicotinic acid test in Gilbert's syndrome and to investigate if there exists a correlation between parameters of this test and the reduced

Table 2 Area under bilirubin concentration time curve $(A U C)$ and increment of serum unconjugated bilirubin after giving nicotinic acid to controls and to patients with Gilbert's syndrome, having normal or raised fasting total bilirubin levels

\begin{tabular}{|c|c|c|c|}
\hline \multirow{2}{*}{$\begin{array}{l}\text { Fasting serum } \\
\text { bilirubin: }\end{array}$} & \multirow{2}{*}{$\begin{array}{l}\text { Controls } \\
\text { Normal } \\
(<17 \cdot 1 \mu \mathrm{mol} / 1)\end{array}$} & \multicolumn{2}{|c|}{ Gilbert's syndrome } \\
\hline & & $\begin{array}{l}\text { Normal } \\
(<17 \cdot 1 \mu \mathrm{mol} / 1)\end{array}$ & $\begin{array}{l}\text { Raised } \\
(>17 \cdot 1 \text { rmol/1) }\end{array}$ \\
\hline & $2 \cdot 72$ & $5 \cdot 10$ & 3.95 \\
\hline & $2 \cdot 74$ & $5 \cdot 88$ & $5 \cdot 81$ \\
\hline \multirow[t]{2}{*}{ AUC } & $2 \cdot 89$ & $6 \cdot 36$ & 6.53 \\
\hline & $2 \cdot 91$ & 6.45 & 7.93 \\
\hline \multirow[t]{4}{*}{$(\mathrm{mmol} / \mathrm{min} / 1)$} & $2 \cdot 92$ & 8.07 & 9.90 \\
\hline & 3.06 & & $10 \cdot 24$ \\
\hline & $4 \cdot 34$ & & $10 \cdot 62$ \\
\hline & & & $16 \cdot 54$ \\
\hline \multirow[t]{3}{*}{$x \pm$ SD } & $3 \cdot 08 \pm 0 \cdot 57$ & $6 \cdot 37 \pm 1 \cdot 09$ & $8.94 \pm 3.87$ \\
\hline & $(n=7)$ & $(n=5 ; p<0.001)$ & $(n=8 ; p<0.01)$ \\
\hline & 6.8 & $17 \cdot 1$ & $12 \cdot 5$ \\
\hline \multirow{7}{*}{$\begin{array}{l}\text { Max. increment of } \\
\text { unconj. bilirubin } \\
(\mu \mathrm{mol} / 1)\end{array}$} & $6 \cdot 8$ & $20 \cdot 2$ & $15 \cdot 2$ \\
\hline & $8 \cdot 2$ & $21 \cdot 0$ & $21 \cdot 7$ \\
\hline & $10 \cdot 1$ & $31 \cdot 5$ & $23 \cdot 1$ \\
\hline & $11 \cdot 1$ & $35 \cdot 9$ & $25 \cdot 5$ \\
\hline & $13 \cdot 0$ & & $27 \cdot 5$ \\
\hline & $15 \cdot 4$ & & $30 \cdot 9$ \\
\hline & & & $31 \cdot 1$ \\
\hline $\mathbf{x} \pm \mathbf{S D}$ & $\begin{array}{c}10 \cdot 2 \pm 3 \cdot 2 \\
(n=7)\end{array}$ & $\begin{array}{c}25 \cdot 1 \pm 8 \cdot 1 \\
(n=5 ; p<0 \cdot 02)\end{array}$ & $\begin{array}{c}23.4 \pm 6.8 \\
(n=8 ; p<0.001)\end{array}$ \\
\hline
\end{tabular}

hepatic bilirubin clearance characteristic of this condition.

For this purpose 13 patients were studied who met the generally accepted criteria of Gilbert's syndrome ${ }^{24}$ - that is, recurrent unconjugated hyperbilirubinaemia with normal liver function tests and absence of overt haemolysis. They were compared with seven healthy controls.

In both groups nicotinic acid injection resulted in a

$$
\begin{array}{lll}
\text { Increment of } & \text { Retention } & \text { AUC } \\
\text { Unconj. Bilirubin } & 4 \text { hours } & \mathrm{mmol} \cdot \mathrm{min} \cdot \mathrm{l}^{-1} \\
\mathrm{\mu mol} \mathrm{l}^{-1} & \% &
\end{array}
$$

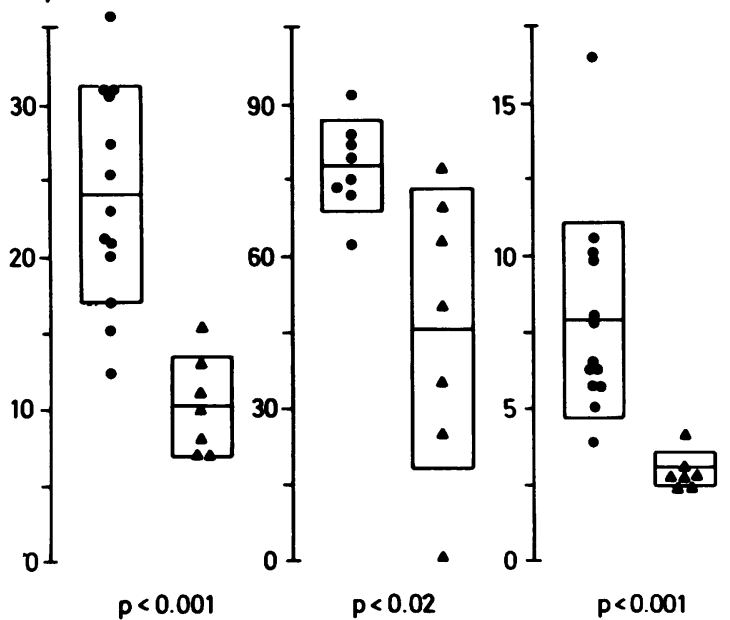

Fig. 2 Comparison of increment of unconjugated bilirubin, retention at four hours, and area under the bilirubin concentration time curve $(A U C)$ in Gilbert's syndrome (•) and controls $(\Delta)$. Horizontal bars are means \pm standard deviations. 


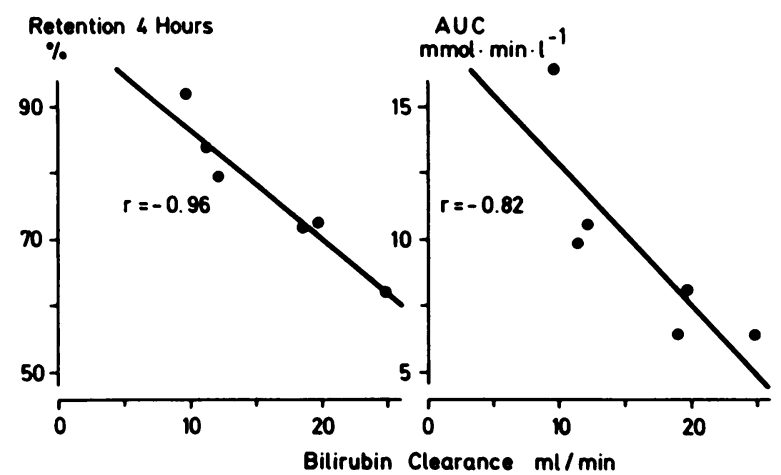

Fig. 3 Correlation between the estimated bilirubin clearance (without treatment) and (1) the bilirubin retention at four hours, and (2) the area under the bilirubin concentration time curve (AUC), in six patients with Gilbert's syndrome after nicotinic acid injection.

rise of unconjugated serum bilirubin; the concentration-time curves, however, were quite different from each other. Compared with controls, patients with Gilbert's syndrome showed a steeper increment, a higher and later peak, and a significant delay in the clearance of unconjugated bilirubin at the end of the test. This agrees well with results of recent studies. ${ }^{4112}$ Thus, the pre-injection values and the increments in bilirubin concentrations observed in this study are comparable with those found by Fromke ${ }^{4}$ and Ohkubo. ${ }^{12}$ The retention values, however, are not comparable because, in the present study, the test was performed during a period of four hours, as compared with an observation period of five hours used by the other authors.

Besides the maximal increment and the retention of unconjugated bilirubin, the AUC was introduced as a new test parameter. Significant differences between patients and controls were found with regard to each of these parameters (Fig. 2). Of those, the AUC discriminated best between patients with Gilbert's syndrome and controls.

In agreement with Ohkubo ${ }^{12}$ we found that an increase of unconjugated serum bilirubin of more than $17 \cdot 1 \mu \mathrm{mol} / \mathrm{l}$ in this test is highly suspicious of Gilbert's syndrome.

Another aim of this study was to see what relationship exists between parameters of this test and the reduced hepatic bilirubin clearance characteristic of Gilbert's syndrome. As shown in Fig. 3 the bilirubin clearance correlated significantly with both the retention and the AUC. Therefore, the characteristic bilirubin concentration time curve after nicotinic acid injection in patients with Gilbert's syndrome may be regarded as a result of the reduced hepatic bilirubin clearance.
In the present study in five of 13 patients with Gilbert's syndrome (39.0\%) the initial bilirubin levels were normal. After nicotinic acid injection, however, a positive response was found not only in subjects with raised bilirubin levels, but also in those whose initial bilirubin concentrations were normal (Table 2). These results are similar to those of Davidson $e t$ al. ${ }^{10}$ who compared the nicotinic acid test with the low calorie intake test (400 calories for 48 hours). In patients with Gilbert's syndrome these authors found a significant increase of total and unconjugated bilirubin only in the nicotinic acid test but not in the low calorie test. Furthermore, in two patients initial bilirubin levels were normal but increased significantly after nicotinic acid.

The provocation with nicotinic acid, therefore, should prove valuable as an additional test in patients with suspected Gilbert's syndrome, especially in those whose bilirubin level at the time of investigation has fallen to normal.

\section{References}

'Barret PVD, Berk PD, Menken M, Berlin NJ. Bilirubin turnover studies in normal and pathologic states utilizing bilirubin- ${ }^{14} \mathrm{C}$. Ann Intern Med 1968; 68: 355-77.

${ }^{2}$ Berk PD, Bloomer JR, Howe RB, Berlin NJ. Constitutional hepatic dysfunction (Gilbert's syndrome). A new definition based on kinetic studies with unconjugated radiobilirubin. Am J Med 1970; 49: 296-305.

${ }^{3}$ Black M, Billing BH. Hepatic bilirubin UDP-glucuronyltransferase activity in liver disease and Gilbert's syndrome. N Engl J Med 1969; 280: 1266-71.

${ }^{4}$ Fromke VL, Miller D. Constitutional hepatic dysfunction (CHD): a review with special reference to a characteristic increase and prolongation of the hyperbilirubinemic response to nicotinic acid. Medicine 1972; 51: 451-64.

${ }^{5}$ Mattei C. Sui vari aspetti della curva bilirubinemica da carico di acido nicotinico nei normali e negli epatopazienti. Minerva Med 1946; 37: 308-13.

${ }^{\circ} \mathrm{G} y d e l l ~ K$. On the hyperbilirubinemic and hypersideremic action of nicotinic acid on normal subjects and on patients with some hematological disorders. Acta Med Scand 1958; 162: 9-27.

${ }^{7}$ Gydell K. Transient effect of nicotinic acid on bilirubin metabolism and formation of carbon monoxide. Acta Med Scand 1960; 167: 431-41.

${ }^{8}$ Marfori L, Stefanini M, Bramante P. Clinical significance of hyperbilirubinemia due to nicotinic acid. Am J Med Sci 1947; 213: 150.

${ }^{9}$ Fink Ch, Jorke D. Liver function test after nicotinic acid loading: a clinical study. Acta Hepatosplenol 1968; 15: 315-321.

${ }^{10}$ Davidson AR, Rojas-Bueno A, Thompson RPH, Williams R. Reduced caloric intake and nicotinic acid provocation tests in the diagnosis of Gilbert's syndrome. Br Med J 1975; 2: 480.

${ }^{1}$ Sato E, Fujita K. Inagaki T, Inoue K, Sasaki H, Ichida F. 
Clinical significance of nicotinic acid provocation test in Gilbert's disease. Jap J Gastroenterol 1977; 74: 774-8.

${ }^{12}$ Ohkubo H, Mushe H, Okuda K. Studies on nicotinic acid interaction with bilirubin metabolism. Dig Dis Sci 1979; 24: 700-04.

${ }^{13}$ Tygstrup N. Determination of the hepatic elimination capacity of galactose by single injection. Scand J Clin Lab Invest 1966; 18: 118-25.

${ }^{14}$ Häcki W, Bircher J, Preisig R. A new look at the plasma disappearance of sulfobromophthalein (BSP): correlation with the BSP transport maximum and the hepatic plasma flow in man. J Lab Clin Med 1976; 88: 1019-31.

${ }^{15}$ Bircher J, Küpfer A, Gikalov J, Preisig R. Aminopyrine demethylation measured by breath analysis in cirrhosis. $J$ Clin Pharmacol Ther 1976; 20: 484-92.

${ }^{16}$ International Committee for Standardization in Hematology. Recommended methods for radioisotope red cell survival studies. Blood 1971; 38: 378-86.

${ }^{17}$ Kutz K, Egger G, Bachofen H, Preisig R. Eine einfache Methode zur Berechnung der hepatischen Bilirubin clearance: ihre Anwendung bei Patienten mit GilbertSyndrom. Helvetica Medica Acta 1974; 37: 386-7.

${ }^{18}$ Michaelsson M, Nosslin B, Sjölin S. Plasma bilirubin determination in the newborn infant. A methodological study with special reference to the influence of hemolysis. Pediatrics 1965; 35: 925-31.

${ }^{19}$ Kutz K, Egger G, Bachofen H, Preisig R. Effect of fasting on endogenous carbon monoxide production in normal subjects and those with constitutional hepatic dysfunction. In: Berk PD, Berlin NI, eds. Chemistry and physiology of bile pigments. Bethesda, USA: DHEW publication No (NIH) 77-1100, 1977: 156-67.

${ }^{20} \mathrm{Hjelm}$ MA. A methodological study of the enzymatic determination of galactose in human whole blood, plasma, and erythrocytes with galactose oxidase. Clin Chim Acta 1967; 15: 87-96.

${ }^{21}$ Preisig R, Williams R, Sweeting J, Bradley SE. Changes in sulfobromphthalein transport and storage by the liver during viral hepatitis in man. Am J Med 1966; 40: 170-83.

${ }^{22}$ Bircher J, Blankart R, Halpern A, Häcki W, Laissue J, Preisig R. Criteria for assessment of functional impairment in patients with cirrhosis of the liver. Eur J Clin Invest 1973; 3: 72-85.

${ }^{23}$ Heri M. Die Galaktoseeliminationskapazität. Universität Bern: Dissertation, 1979.

${ }^{24}$ Powell LW, Hemingway E, Billing BH, Sherlock S. Idiopathic unconjugated hyperbilirubinemia (Gilbert's syndrome). N Engl J Med 1967; 277: 1108-12. 